\title{
EVALUATION OF THE IMPACT OF DISINFECTION PROCESSES ON THE FORMATION OF BIOFILMS IN POTABLE SURFACE WATER DISTRIBUTION SYSTEMS
}

\author{
Maggy N. B. Momba, T. E. Cloete, S. N. Venter and R. Kfir
}

\section{INTRODUCTION}

Potable water should not contain pathogenic microorganisms. To achieve this goal, water suppliers have to use disinfectants such as chlorine, chloramine, ozone, UV irradiation and hydrogen peroxide. However, it is well known that these substances easily deteriorate and may promote biofilm formation in distribution systems (Lund and Ormerod, 1995). Consequently, this results in the deterioration of the microbial quality of water treated and supplied for drinking and other domestic purposes. The deterioration of the bacteriological water quality in the distribution systems is currently one of the main problems facing potable water suppliers. Attention has been associated with this deterioration. Studies have shown that biofilm formation or bacterial regrowth in potable water systems occur mainly due to the presence of nutrients (van der Wende and Characklis, 1990), and that bacteria embedded in matrices (extracellular polymer substances) in biofilms are protected from disinfectants (Fletcher and Marshall, 1982; LeChevallier et al, 1988). The presence of biofilms leads to continuous contamination of the water phase resulting from the release of the attached growing biomass (Paquin et al, 1992).

To limit the accumulation of bacteria in potable water and the formation of biofilm in potable water distribution systems, two parameters must be taken into account: the disinfection efficiency and the presence of the disinfectant residual. However, researchers have shown that less reactive, more persistent, monochloramine maintained a longer disinfectant residual through distribution systems and could penetrate the biofilm more effectively and thus, control biofilm organisms better than free chlorine (LeChevallier et al, 1990; van der Wende and Characklis, 1990). Maintenance of a chlorine residual does not eliminate all bacteria in a water distribution system. Lechevallier et al. (1990) showed that biofilms grown on iron pipes treated with free chlorine doses as high as $4 \mathrm{mgl}^{-1}\left(3 \mathrm{mgl}^{-1}\right.$ residual) for two weeks did not show a significant change in viability, but if treated with $4 \mathrm{mgl}^{-1}$ of monochloramine for two weeks, these biofilms exhibited a more than $3 \log$ die-off. The study performed by Clark et al. (1994) showed that, after various combinations of ozone, chlorination and chloramination, microorganisms increased on fixed pipe surfaces when disinfectant residual disappeared. A study performed by Lund and Ormerod (1995) showed that no biofilm was formed from chlorinated water containing a residual of 0.04-0.05 mg. $\mathrm{l}^{-1}$. Most prolific regrowth was found in ozonated water, followed by the control (microstrained) water. UV irradiated water showed considerably less production of biofilm.

If the efficiency of disinfection processes and the presence of residual disinfectant in the system were well identified, it would be possible to find the role that disinfection processes play in the reduction of the water quality in potable water distribution systems. During this study, surface water was used to evaluate a number of disinfection processes concurrently (chlorination, chloramination, ozonation, UV irradiation and hydrogen peroxide) and the impact of these processes on the formation of biofilms.

\section{MATERIALS AND METHODS}

\section{Water sources}

Partially treated surface waters were collected from water treatment plant (Rand Water Board). The treatment comprised coagulation (70 mg. $\mathrm{l}^{-1}$ lime, $2.2 \mathrm{mg} . \mathrm{l}^{-1}$ sodium silica followed by $1.5 \mathrm{mg} . \mathrm{l}^{-1} \mathrm{FeCI}_{3}$ ), 
flocculation, sedimentation and filtration. Before filtration, the $\mathrm{pH}$ of the water was adjusted from 11 to 8.4 with $\mathrm{CO}_{2}$. This water was used as control during the experimental period.

\section{Distribution system laboratory- scale unit}

Figure one illustrates schematically the laboratory scale unit used as a batch reactor. Five batch reactors were used for disinfected water and one for the control. Waters circulated in different systems at a flow rate of 2.79.h.I I $^{-1}$.

\section{Disinfection processes}

No neutralization was applied during the experimental period of any of the disinfectants used for the source water, with the exception of samples on which microbiological analysis were conducted. To evaluate the impact of disinfection processes on biofilm formation, different disinfectants were applied with doses similar to those used in practise.

\section{Chlorination}

Chlorinated water was produced by the addition of a $2.5 \mathrm{mg} \cdot \mathrm{l}^{-1}$ free chlorine solution. The concentration of the residual free chlorine was measured using the N,N-diethyl-phenylenediamine (DPD-Sigma) ferrous titrimetric method (APHA, AWWA, WPCF, 1989).

\section{Chloramination}

Chloramination was accomplished using $2.5 \mathrm{mg} \cdot \mathrm{l}^{-1}$ monochloramine solution. The monochloramine solution was prepared by reacting the chlorine solution with $\mathrm{NH}_{4} \mathrm{Cl}$ solution at $\mathrm{NH}_{4}: \mathrm{Cl}$ mass ratio of $4: 1$. The concentration of the residual monochloramine was measured using the N,N-diethyl-phenylenediamine (DPD-Sigma) ferrous titrimetric methods (APHA, AWWA, WPCF, 1989).

\section{$\underline{\text { Ozonation }}$}

Ozonated test water was produced by using an ozonator (Degremont), consisting of a tube-type oxygen-fed, water-cooled unit. Ozonation took place in a batch bubble column reactor with a volume of 11 . The ozone was applied at $2.60 \mathrm{mg} \cdot \mathrm{l}^{-1}$ and a contact time of $5 \mathrm{~min}$. The residual ozone was measured using the indigo colorimetric method according to standard method (APHA-AWWA-WPCF, 1989).

\section{UV Irradiation}

An ultra-violet irradiation unit (Willand UV systems, represented in South Africa by UV Water Systems (Pty) Ltd), installed in the laboratory, was able to disinfect water at the flow rate of $5.41 / \mathrm{min}$, at a $30 \mathrm{~m}$ $\mathrm{Ws} / \mathrm{m}^{2}$ dosage.

\section{Hydrogen peroxide}

Water was disinfected with hydrogen peroxide at a concentration of $19.43 \mathrm{mg} . \mathrm{l}^{-1}\left(50 \% \mathrm{H}_{2} \mathrm{O}_{2}\right.$, Alliance Peroxide). The residual hydrogen peroxide was determined using the RQflex reflectometer (Reflectoquant 16974, Merck).

\section{$\underline{\text { Sampling and biofilm analyses }}$}

Biofilm experiments were conducted when the control and disinfected waters were present in different systems (Figure 1). Coupons were withdrawn $24 \mathrm{~h}$ after disinfection and weekly for a period of $22 \mathrm{~d}$ for cement coupons and $38 \mathrm{~d}$ for stainless steel coupons. 


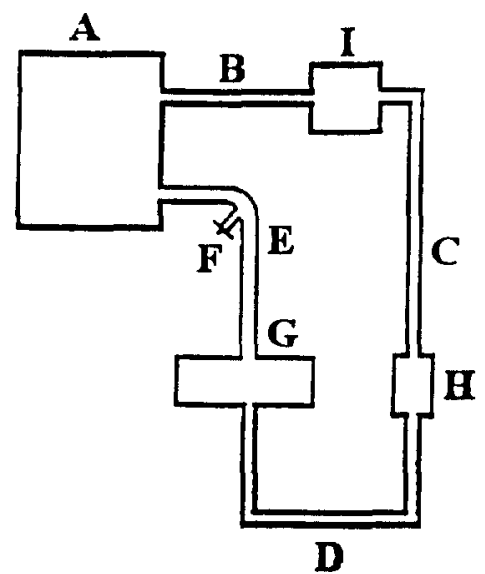

Figure 1. Schematic diagram of the laboratory-scale unit (A) the strile drum; (B), (C), (D), (E) the latex tubing facilitating the water circulation; $(\mathrm{F})$ the tap facilitating the sampling, $(\mathrm{G})$ the Pedersen device, $(\mathrm{H})$ the flow-through glass tube; (I) the peristaltic pump.

\section{Biofilm monitoring}

Biofilm monitoring was done using a spectrophotometric method. The Merck SQ 118 photometer was adjusted to a wavelength of $550 \mathrm{~nm}$. An absorbance measurement of the bacteria attached to the flowthrough glass tube was determined simultaneously with the absorbance of bacteria in water sample present in the flow-through glass tubes. The absorbance measurement was determined at the same frequency as for coupons.

\section{Attached heterotrophic bacteria}

Attached bacteria were released from stainless steel $(25 \times 25 \times 1 \mathrm{~mm})$ and cement coupons by 2 min sonication in $20 \mathrm{ml}$ sterile MilliQ water. Heterotrophic bacteria were enumerated by the standard spread plate procedure using R2A agar (Difco), incubated at $28^{\circ}$ for $7 \mathrm{~d}$. Analyses were carried out in triplicate. The following equation was used to calculate the number of heterotrophic plate count (HPC) bacteria $\left(\mathrm{cfu} . \mathrm{cm}^{-2}\right): \mathrm{cfu}^{-\mathrm{cm}^{-2}}=\mathrm{N}$ x D/ Surface area of coupons

$$
\begin{aligned}
& \mathrm{N}=\text { average number of colonies } \\
& \mathrm{D}=\text { dilution factor }
\end{aligned}
$$

Table 1 . The residual disinfectant concentrations in the laboratory scale units

\begin{tabular}{lcccc}
\hline & \multicolumn{4}{c}{ Residual disinfectants $\left(\mathrm{mg} .0^{-1}\right)$} \\
\cline { 2 - 5 } Exposure time & free chlorine & chloramine & ozone & hydrogen peroxide \\
\hline & 2.5 & 2.5 & 2.6 & 19.43 \\
0 & 1.2 & 1.2 & - & - \\
$20 \mathrm{~min}$ & - & - & 0.02 & - \\
$2 \mathrm{~h}$ & 0.2 & 1.0 & 0.0 & 16.50 \\
$1 \mathrm{~d}$ & 0.0 & 0.8 & 0.0 & 13.00 \\
$2 \mathrm{~d}$ & 0.0 & 0.5 & 0.0 & 4.90 \\
$3 \mathrm{~d}$ & 0.0 & 0.3 & 0.0 & 1.60 \\
$8 \mathrm{~d}$ & 0.0 & 0.0 & 0.0 & 0.70 \\
$15 \mathrm{~d}$ & 0.0 & 0.0 & 0.0 & 0.00 \\
$22 \mathrm{~d}$ & & & & \\
\hline
\end{tabular}




\section{RESULTS AND DISCUSSION}

To evaluate the impact of disinfection processes on biofilm formation, different disinfectants were applied with doses similar to those used in practise. A reduction of free chlorine concentration (Table 1) occurred from $2.5 \mathrm{mgl}^{-1}$ to $1.2 \mathrm{mg} . \mathrm{l}^{-1}$ within $20 \mathrm{~min}$, and progressively decreased to $0.2 \mathrm{mg} .1^{-1}$ during the next $24 \mathrm{~h}$ and to zero after $48 \mathrm{~h}$. The monochloramine concentration decreased from 2.5 to $1.2 \mathrm{mg} \cdot \mathrm{l}^{-1}$ within $20 \mathrm{~min}$ after disinfection. The residual monochloramine could be detected up to $8 \mathrm{~d}$ (Table 1). The ozone concentration decreased from 2.60 to $0.02 \mathrm{mg} . \mathrm{l}^{-1}$ within $2 \mathrm{~h}$ after disinfection and could not be detected after $24 \mathrm{~h}$. As to the hydrogen peroxide, a decrease occurred from 19.43 to $16.50 \mathrm{mg} . \mathrm{l}^{-1}$ within $1 \mathrm{~d}$, and the residual could be detected up to $15 \mathrm{~d}$ (Table 1 ).

Biofilm formation on the flow-through glass tubes, stainless steel coupons and cement coupons is shown in Figures 2-4. The adhesion of bacteria on the glass surfaces could be seen with the naked eye after an exposure time of $1 \mathrm{~d}$. This was confirmed by the direct absorbance measurements (Figure 2). Bacteria also started to adhere to the stainless steel (Figure 3) and cement (Figure 4) coupons within the first day after disinfection. The yield in viable count was higher on stainless steel coupons than on cement coupons within the first 8 days. While the viable count from UV irradiated water was higher on stainless steel coupons, a low yield was detected on cement coupons after the exposure time of $1 \mathrm{~d}$. Within $8 \mathrm{~d}$, viable counts from cement coupons were similar in chlorinated water, ozonated and UV water whereas low count was noted in hydrogen peroxide treated water and chloramine treated water. The lowest viable count was noted on cement coupons exposed to hydrogen peroxide treated water (Figure 4). This demonstrated the inability of attached bacteria to regrow in the presence of a significant concentration of disinfectant residual $\left(1.6 \mathrm{mg} . \mathrm{l}^{-1}\right.$ hydrogen peroxide) and also showed that monochloramine and hydrogen peroxide residuals did limit the increase of fixed bacteria on the coupons.

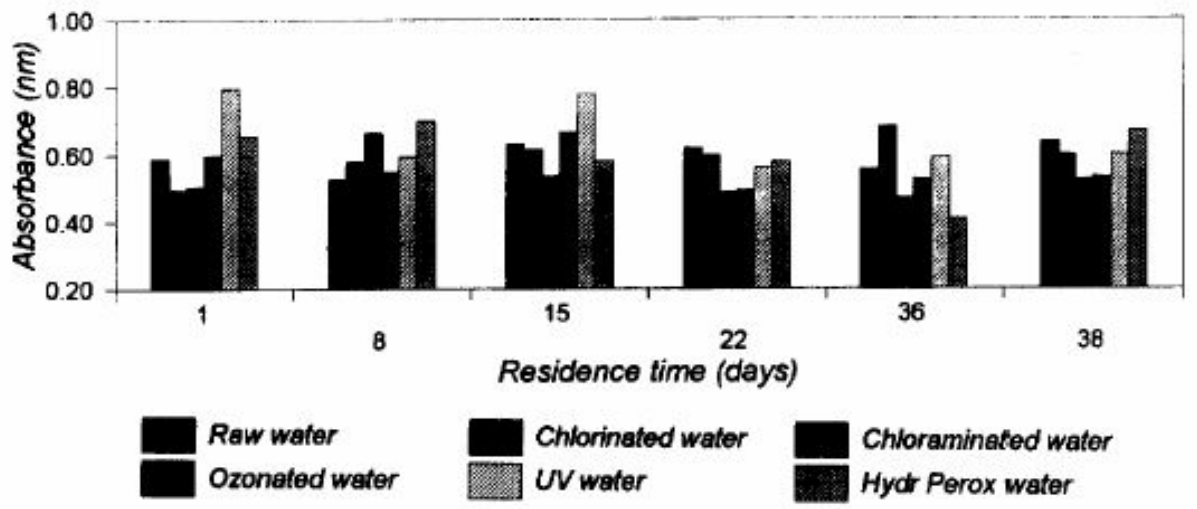

Figure 2. Measurement of attached bacteria on flow-through glass surfaces in different water distribution systems.

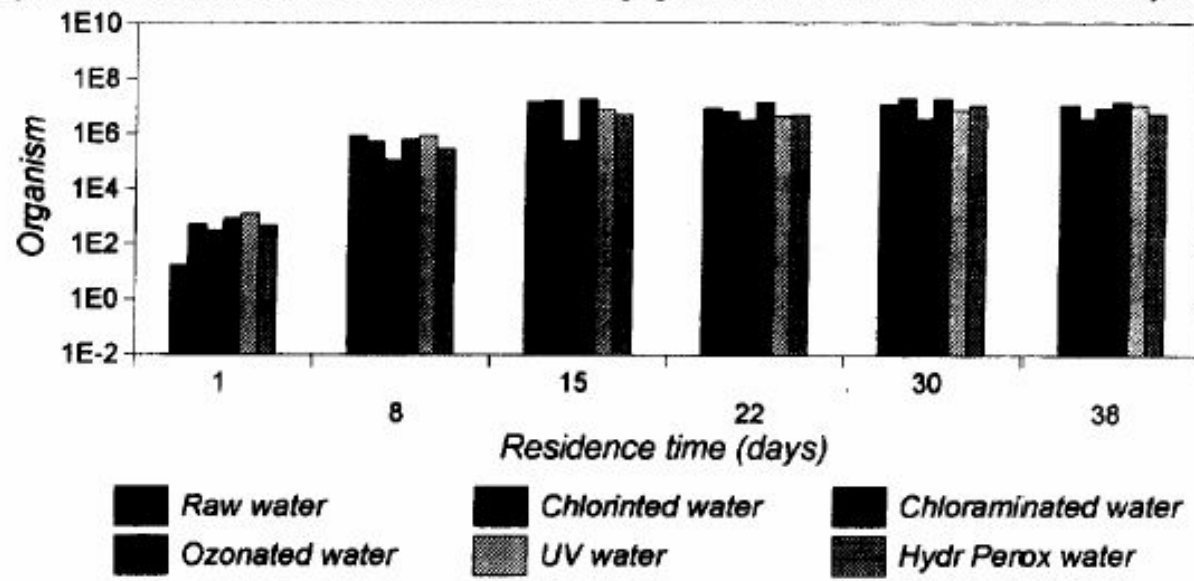

Figure 3. Composition of attached heterotrophic bacteria on stainless steel coupons in different water distribution systems. 
Even in the presence of important residual disinfectants $\left(16.50 \mathrm{mg} . \mathrm{l}^{-1}\right.$ hydrogen peroxide, $1 \mathrm{mg} . \mathrm{l}^{-1}$ monochloramine, $0.2 \mathrm{mg} .1^{-1}$ free chlorine), the attachment of bacteria to the coupons was obvious. This experiment showed that the maintenance of a disinfectant residual in potable water could not be relied on to prevent bacteria adhesion and formation of biofilm on stainless steel coupons, cement coupons and glass surfaces. On one hand, our observations support van der Wende and Characklis (1990) who found, with an experimental Roto Torque System (RTS), the accumulation of biomass in the system with the high chlorine concentration ( $0.8 \mathrm{mg} . \mathrm{l}^{-1}$, after exposure time of 17 and $\left.38 \mathrm{~d}\right)$ as well as with the low chlorine concentration $\left(0.2 \mathrm{mgl}^{-1}\right.$ after exposure times of 17 and $\left.45 \mathrm{~d}\right)$. On another hand, this study is not in agreement with Lund and Ormerod (1995) who found that a free chlorine as low as $0.05 \mathrm{mg} \cdot \mathrm{l}^{-1}$ was sufficient to prevent sludge production on the pipe walls, and when the authors reported that less production of biofilm in UV irradiated water, although the difference in methods could explain the fact.

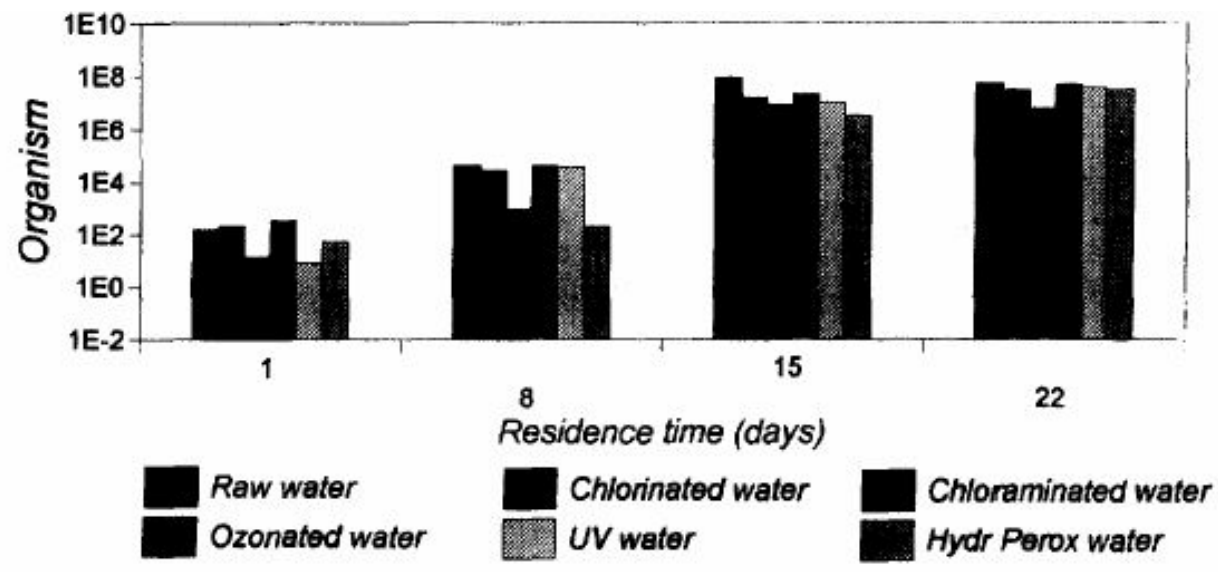

Figure 4. Composition of attached heterotrophic bacteria on cement coupons exposed in different water distribution systems.

Prolonged exposure ( $22 \mathrm{~d}$ for cement coupons and $38 \mathrm{~d}$ for stainless steel coupons) resulted in the increase of viable counts of biofilm cells. Chloraminated water revealed a somewhat lower average viable count of biofilm cells than other treated water. One explanation could be related to an effective residual monochloramine which could be detected up to $8 \mathrm{~d}$.

Although average viable counts of biofilm cells from cement coupons appeared to be higher $\left(1.4 \times 10^{7} \mathrm{cfu}\right.$ . $\left.\mathrm{cm}^{-2}\right)$ than those from stainless steel coupons $\left(7.88 \times 10^{6} \mathrm{cfu}^{-\mathrm{cm}^{2}}\right)$ after 22 days, ANOVA (alpha $\left.=0.05\right)$ showed no significant difference $(\mathrm{P}=0.8032)$ between the two.

\section{CONCLUSION}

Whatever the disinfectants used, biofilm formation occurred on stainless steel and cement coupons in laboratory scale units. High residual disinfectants of $16.5 \mathrm{mg} \cdot \mathrm{l}^{-1}$ hydrogen peroxide and $1 \mathrm{mgl}^{-1}$ monochloramine as well as a free chlorine concentration of $0.2 \mathrm{mg} \cdot 1^{-1}$ were not found to prevent the formation of biofilms.

\section{ACKNOWLEDGEMENTS}

Authors wish to express their thanks to the Council for Scientific and Industrial Research (C.S.I.R) Pretoria, South Africa who sponsored this investigation. 


\section{REFERENCES}

American Public Health Association (1989). Standard Methods for the Enumeration of Water and Wastewater, 17 ed. American Public Health Association, American Water Works Association and Water Pollution Control Federation, Washington, DC.

Clark, R. M., Lykins, B. W., Block, J. C, Wymer, L. J. and Reasoner, D. J. (1994). Water quality changes in a simulated distribution system. J. Wat. SRT - Aqua, 43(6), 263-277.

Fletcher, M. and Marshall, K. C. (1982). Bubble contact angle method for evaluation of substratum interfacial characteristics and its relevance to bacterial attachment. App. Environ. Microbiol, 44, 797-732.

LeChevallier, M. W., Cawthon, C. D. and Lee, R. G. (1988). Factors promoting survival of bacteria in chlorinated water supplies. App. Environ. Microbiol., 54, 644.

LeChevallier, M. W., Cawthon, C. D. and Lee, R. G. (1988). Mechanisms of bacterial survival in chlorinated drinking water. Wat. SciTech., 20 (11/12), 145-151.

LeChevallier, M. W., Lowry, C. D. and Lee, R. G. (1990). Disinfecting biofilms in a model distribution system. J. Amer. Wat. Works Ass., 82, 87-99.

Lund, V. and Ormerod, K. (1995). The influence of disinfection processes on biofilms formation in water distribution systems. Wat. Res., 99(4), 1013-1021.

Paquin, J. L., Hartemann, P., Block, J. C, Colin, F., Miazga, J. and Levi, Y. (1992). Effet du chlore sur la colonisation bacterienne d'un reseau experimental de distribution d'eau. Science de I'eau, 5, 399-414.

van der Wende, E. and Characklis, W. G. (1990). Biofilms in potable water distribution systems. In Drinking Water Microbiology, Progress and Recent Developments, McFeters, G. A. (ed), pp. 249-268. Springer-Verlag, New-York. 